Original Paper

\title{
Alkaline-peroxide Treatment for Enzymatic Hydrolysis of Japanese Cypress (Chamaecyparis obtusa)
}

\author{
Akihiro Hideno ${ }^{* 1}$, Ayato KAWASHIMA ${ }^{* 2}$, Masatoshi MoRITA ${ }^{* 2}$, \\ Katsuhisa HONDA ${ }^{* 2}$, Takashi ENDO *3 \\ (Received March 5, 2013)
}

\section{ヒノキ (Chamaecyparis obtusa) 酵素糖化のためのアルカリ - 過酸化水素法の検討 秀野晃大 ${ }^{*}$, 川嶋文人 ${ }^{2}$, 森田昌敏 ${ }^{2}$, 本田克久 ${ }^{2}$, 遠藤貴士 $* 3$}

In Japan, softwood is one of the suitable materials for production of bio-fuels, since forest of softwood accounts approximately 90\% in artificial forest in Japan, and it is widely used for constructing the traditional Japanese house. Japanese cypress (Chamaecyparis obtusa), which is known for its high quality lumber has been attracted a lot of interest as a potential feedstock in Japan. The conditions of alkaline peroxide pretreatment were investigated for the enzymatic hydrolysis of Japanese cypress in this study. The suitable condition of the pretreatment was as follows; at $70{ }^{\circ} \mathrm{C}$ with $2 \mathrm{M}$ sodium hydrate $(\mathrm{NaOH})$ of and $6 \mathrm{M}$ hydrogen peroxide $\left(\mathrm{H}_{2} \mathrm{O}_{2}\right)$. Almost of hemicellulose and approximately $60 \%$ of lignin were disappeared in the AP-pretreated sample. The AP-pretreated sample had the high-crystallinity and the celluolose nano fibers and nano scale "raising" on the surface. The suitable enzyme was Accellease1500 resulted in approximately 60\%-glucose yield with 20 mgprotein/g-substrate. These results suggest that the alkaline peroxide hydrogen treatment has the potential as the pretreatment for obtaining glucose from softwood such as Japanese cypress in enzymatic hydrolysis.

\section{Key Words}

Alkaline-peroxide treatment, Japanese cypress, Enzymatic hydrolysis

日本では，人工林の約 9 割が針葉樹林であり，針葉樹はバイオ燃料の原料として適している素材の一つである。中でも ヒノキ (Chamaecyparis obtusa) は耐腐朽性の高い高品質建築材として, 伝統的な日本家屋の建築で用いられてきた。本研 究では, ヒノキの高効率酵素糖化を目指し, アルカリ - 過酸化水素法の単独処理を検討した。6 $\mathrm{M}$ 過酸化水素および $2 \mathrm{M}$ 水酸化ナトリウムの混合試薬中で, $70^{\circ} \mathrm{C}, 12$ 時間以上反応させる条件がヒノキの酵素糖化に最適であった。本処理によって, ヒノキに含まれる大部分のへミセルロース抽び $60 \%$ のリグニンが分解, 溶出し, 処理材表面にセルロースナノファイバーお よびナノスケールの “毛羽立ち”が露出することで, 高結晶性を有するものの, 高糖化率が可能な素材となった。本処理材 の至適糖化酵素を検討した結果, Acellerase1500 が選択され，さらに酵素使用量の低減化が示された。本研究により，ア ルカリ - 過酸化水素法およびAccellerase1500の組み合わせが，針葉樹であるヒノキの高効率酵素糖化に有効であること が明らかになった。

キーワード

アルカリ - 過酸化水素法, ヒノキ, 酵素糖化

※ 1 Senior Research Fellow Center, Ehime University 3-5-7 Tarumi, Matsuyama, Ehime 790-8566, Japan

$※ 2$ Faculty of agriculture, Ehime University 3-5-7 Tarumi, Matsuyama, Ehime, 790-8566, Japan

※3 Biomass Refinery Technology Research Center, National Institute of Advanced Industrial Science and Technology (AIST)

3-11-32 Kagamiyama, Higashi-Hiroshima, Hiroshima 737-0046, Japan

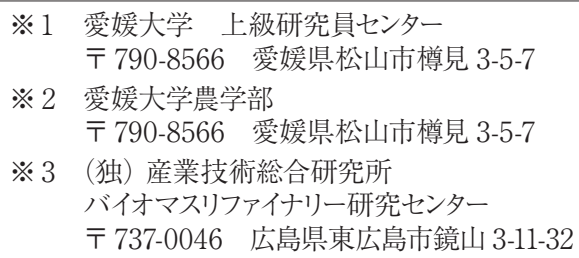




\section{1. 緒 言}

地球温暖化防止に向けた二酸化炭素削減や循環型社会構 築, 環境産業の主導権確保という観点から石油代替となるバ イオエタノールの生産が活発であった。最近になって, シェー ルオイルの登場や穀物価格の上昇を理由にサトウキビやトウ モロコシといった可食資源を利用したバイオエタノール生産の 減産が検討されている。しかし脱原発の流れもあり，食糧 や飼料と競合しない第二世代バイオエタノールと呼ばれる, 非食植物資源のセルロース系バイオマスを用いたバイオエ夕 ノールの開発が求められている11。

一方，デジタル機器類の発達や資源保護の観点から，情 報媒体としての紙の役割が小さくなり，紙の消費量が減少す るといわれている。国内でも，人口の減少や広告媒体の多 様化から紙の需要減を避けることは困難である。国内に点 在する約 100 力所の製紙工場の多くは設備も古く，国外との 競争力バランスから，いずれ収斂されることが予想される。 競争力の無くなった旧型製紙工場を有効活用した木質系バ イオエタノール生産の検討例もあり2) 4), バイオリファイナリー プロセスに応用できる可能性を持っている。

「バイオマス・ニッポン総合戦略」によれば，日本における 廃棄物に関わる木質系バイオマスの年間発生量は, 建設発生 木材，林地残材や未利用樹を合わせて年間約 2400 万 $\mathrm{t}$ にな り，エタノールに換算すると約 540 万 $\mathrm{kL} に$ にぶため 5), 国内 では木質系バイオエタノール製造技術の開発が強く望まれる 6)。日本では国土の約 $66 \%$ が森林で，その内約 4 割が人工林 である7)。人工林の約 9 割は針葉樹林であり, 針葉樹はバ イオ燃料の原料として適している素材の一つである ${ }^{8)}{ }^{9)}$ 。

ヒノキ (Chamaecyparis obtusa) は高品質建築材として伝 統的な日本家屋の建築で用いられてきた。世界最古の木造 建築物である法隆寺でもヒノキが用いられており, 耐腐朽性 の高い材である。我が国の 2007 年におけるヒノキの年間生 産量は, $65,000 \mathrm{~m}^{3}$ であるが, その内約 $70 \%$ が不良品として 使用されずうち捨てられている10)。しかしながら，ヒノキの 高い耐腐朽性は加水分解の困難さを示しており, バイオエ夕 ノール生産の原料として利用する際の問題となるため, 研究 例は数少ない。

木質資源からバイオエタノールを生産するには, 前処理, 糖化, 発酵, 蒸留精製工程が必要である。強固な木材組織 を脆弱にする前処理は重要な工程であり, 本工程の成否によ り後段の糖化で用いられる酵素量や，そこで得られる糖化 率も大きく変わる。酵素コス卜は，以前として製品のエ夕ノー ル生産コストに占める割合が大きいため ${ }^{11)}$, 酵素使用量の削 減化も極めて重要な課題である。

従来の前処理法の一つである濃硫酸法は，既に確立され た技術であるが, 糖の過分解, 中和時に発生する石膏の処 理, 薬品耐性プラントの必要性, 硫酸回収時の消費エネル ギーが大きいことなどが問題になっていた ${ }^{12)}$ 。希硫酸法も, 硫酸中和による石膏発生の問題や薬品耐性プラントの必要 性は同様に存在する。カナダにある Iogen 社の爆砕法は, 低濃度の硫酸を投入しており，基本的に上記と同様の問題

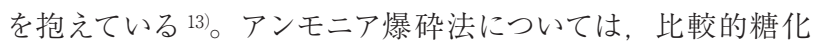
しやすい草本類の研究例が多い ${ }^{14)}$ が, 木材に対する効果に ついて不明な点が多い。

安定剂の入った過酸化水素を用いて行われる Alkaline peroxide 処理は, 環境低負荷型のパルプ漂白として用いら れてきた。一方, 安定剤の入っていない過酸化水素は, 各 種の高反応性酸素分子 (スーパーオキシドやヒドロキシラジ カルなど）を発生しながら分解する。これら過酸化水素由 来のラジカルは, リグニンの低分子化や分解に寄与すると 考えられており，1984 年にGouldによって，アルカリ条件下 で安定剤の入っていない過酸化水素により酸化する Alkaline peroxide 前処理法 (AP 法) が提案された ${ }^{15}$ )。これまでの数 多くの研究がなされ, 麦ワラやコーンコブ等のソフトバイオマ スの酵素糖化に有効であることが示されている 15) 18)。木材 等のハードバイオマスに対しては, 希硫酸処理後の二次処理 として，本法の有効性が示されている19）ものの，木材に対 する $\mathrm{AP}$ 単独処理の効果は不明な点が多い。 $\mathrm{AP}$ 処理で用い られる試薬は, $\mathrm{NaOH}$ および $\mathrm{H}_{2} \mathrm{O}_{2}$ の二種類のみであり, 元々 パルプ漂白で使われているため，本処理は製紙工場で適用 可能である。木材への有効性が示されれば，競争力のなく なった旧型製紙工場を有効活用した木質系バイオエタノール 生産を想定する際，AP 処理は簡易かつ有効な前処理法の 一つとして提案できる。

そこで，本研究では，木質系バイオマスのモデルとしてヒ ノキを用いて, AP 法単独処理の条件検討に続き, AP 処理 材の構成単糖解析および物性評価を行い, AP 処理材に適 した糖化酵素の至適化を試みた。

\section{2. 実験方法}

\section{1 ヒノキ (Japanese cypress : JC)}

木質バイオマスとしてヒノキおが屑を用いた。おが屑を篩 にかけ，125 $\mu \mathrm{m}$ 以上 $500 \mu \mathrm{m}$ 以下のサイズのものをサンプル として用いた。ヒノキおが屑の構成単糖および酸不溶性リグ ニンの分析を Laboratory analytical procedure of the standard National Renewable Energy Laboratory (LAP-NREL) ${ }^{20)}$ に準 じて行った。グルコース (449 mg/g-material), キシロース (44 mg/g-material), マンノース (105 mg/g-material) であり, 酸不溶性リグニンの割合は乾燥重量換算で $31.9 \%$ あった。

\subsection{AP 法の条件検討}

前報 ${ }^{21)}$ に従って, 乾燥重量換算で約 $0.5 \mathrm{~g}$ のヒノキ木粉 が入った $50 \mathrm{ml}$ のエルレンマイヤーフラスコに, $0.25,3 \mathrm{M}$ 水 酸化ナトリウム溶液 (和光純薬工業(株)）拈よび $0.3,6 \mathrm{M}$ 過酸化水素 (和光純薬工業(株)) を合計 $5 \mathrm{ml}$ 入れ, 恒温 振盪機（TAITEC 社製）により $200 \mathrm{rpm}$ で攪拌反応を行っ た。設定温度は $50,70,90^{\circ} \mathrm{C}$ 試し，3〜 21 時間反応さ せた。各反応条件をTable 1 に示す。反応終了後，木綿 布 2 枚を重称た搾り袋に反応物を入れ，流水で約 5 分間洗 浄し, イオン交換水で再洗浄後, エタノールに浸漬し, 余 分なエタノールを搾った後, $55^{\circ} \mathrm{C}$, 約 3 時間の真空乾燥を 
Table 1 Conditions and parameters of the alkaline-peroxide treatments, and the constituent monomeric sugars and percentage of Klason lignin in their residues

\begin{tabular}{|c|c|c|c|c|c|c|c|c|}
\hline \multirow{2}{*}{ Sample name } & \multirow{2}{*}{$\begin{array}{c}\mathrm{H}_{2} \mathrm{O}_{2} \\
(\mathrm{M})\end{array}$} & \multirow{2}{*}{$\begin{array}{c}\mathrm{NaOH} \\
(\mathrm{M})\end{array}$} & \multirow{2}{*}{$\begin{array}{c}\text { Temperature } \\
\left({ }^{\circ} \mathrm{C}\right)\end{array}$} & \multirow{2}{*}{$\begin{array}{c}\text { Solid recovery } \\
(\%)\end{array}$} & \multicolumn{3}{|c|}{ Monomeric sugar content (mg sugar/g substrate) } & \multirow{2}{*}{$\begin{array}{l}\text { Klason lignin } \\
\text { content (\%) }\end{array}$} \\
\hline & & & & & Glucose & Xylose & Mannose & \\
\hline Raw JC & - & - & - & 100 & 449 & 44 & 105 & 31.9 \\
\hline $\mathrm{H}_{2} \mathrm{O}_{2} 6 \mathrm{M}-50$ & 6 & 0 & 50 & 83 & 321 & 36 & 91 & 27.0 \\
\hline $\mathrm{H}_{2} \mathrm{O}_{2} 6 \mathrm{M}-70$ & 6 & 0 & 70 & 77 & 394 & 23 & 57 & 24.7 \\
\hline $\mathrm{NaOH} 2 \mathrm{M}-70$ & 0 & 2 & 70 & 71 & 566 & 33 & 35 & 34.0 \\
\hline $\mathrm{NaOH} 2 \mathrm{M}-90$ & 0 & 2 & 90 & 66 & 517 & 42 & 24 & 39.3 \\
\hline $\mathrm{H}_{2} \mathrm{O}_{2}$ 0.3M/NaOH $2 \mathrm{M}-70$ & 0.3 & 2 & 70 & 69 & 427 & 12 & 50 & 27.8 \\
\hline $\mathrm{H}_{2} \mathrm{O}_{2} 6 \mathrm{M} / \mathrm{NaOH} 2 \mathrm{M}-50$ & 6 & 2 & 50 & 63 & 382 & 36 & 84 & 24.1 \\
\hline $\mathrm{H}_{2} \mathrm{O}_{2} 6 \mathrm{M} / \mathrm{NaOH} 2 \mathrm{M}-70$ & 6 & 2 & 70 & 55 & 460 & 16 & 16 & 21.8 \\
\hline $\mathrm{H}_{2} \mathrm{O}_{2} 6 \mathrm{M} / \mathrm{NaOH} 2 \mathrm{M}-90$ & 6 & 2 & 90 & 42 & 453 & 25 & 5 & 37.5 \\
\hline
\end{tabular}

Raw JC mean the non-treated sample. Other conditions of AP-treatment were the same as follows; reaction duration: 20-21 h, rotary speed: $200 \mathrm{rpm}$.

行った。乾燥試料の重量を測定し，式(1) 用いて固形分収率 (Solid recovery:SR) および式 (2) を用いて重量損失 (Weight loss：WL）を算出した。

固形分収率 (SR) (\%)

$=($ 処理試料の乾燥重量 / 処理前の試料の乾燥重量 $)$

重量損失（WL）（\%）=100-SR（\%)

AP 処理試料の構成単糖および酸不溶性リグニン量の分析を 先述と同様に LAP-NREL ${ }^{20)}$ に準じて行い，単位乾燥重量の AP 処理残渣あたりに含まれる構成糖量として算出した。

\section{3 市販糖化酵素による加水分解試験}

前報 ${ }^{21)}$ に従って, ベース酵素としてアクレモニウムセルラー ゼ (AC，明治製菓(株)）およびAccellerase1500（ACC1500, ジェネンコア協和(株))，アクセサリー酵素として Optimash BG (OPBG, ジェネンコア協和(株)), Optimash XL (OPXL, ジェネンコア協和 (株)）拈よび Novozyme 188 (Nov，ノボ ザイム・ジャパン(株)）を用いて糖化試験を行った。ベース 酵素単独で用いる場合は, $40 \mathrm{mg}$-protein/g substrate (dry weight）で使用し，ベース酵素およびアクセサリー酵素の組 み合わせでは, ベース酵素 $30 \mathrm{mg}$-protein/g-substrate, アク セサリー酵素 10 mg-protein/g-substrate で計 40 mg-protein/ g-substrate で用いた。 $2 \mathrm{~mL}$ セーフックマイクロチューブに, 乾燥重量で約 $0.05 \mathrm{~g}$ の試料を入れ，上記投入量になるよう $0.05 \mathrm{M}$ 酢酸ナトリウム緩衝液（pH4.8）で希釈調整した酵素 液を $1 \mathrm{ml}$ 添加し， $45^{\circ} \mathrm{C}$ に設定した乾熱機（ISUZU Drying Oven, (株)いすが製作所) 内に設置したマイクロチューブロー テーター（MTR-103，アズワン(株)）を用いて，72 時間の酵 素反応を行った。反応終了後, 反応液を遠心分離（20,000 $\times \mathrm{g}, 10$ 分間）の後，上清を適宜希釈し， $0.45 \mu \mathrm{m} \mathrm{PTFE}$ フィルター (Millex-LG, Millipore, USA) でろ過後, HPX-87P カラム (内径 $7.8 \mathrm{~mm}$, 長さ $30 \mathrm{~cm}$, Bio Rad, USA) および 示差屈折率検出器を装着した日本分光高速液体クロマトグ ラフィー システム (LC-2000 plus series, 日本分光 (株)) に
よる生成糖分析を行った。カラムオーブン温度を $80^{\circ} \mathrm{C}$ に設定 し, 高純度イオン交換水を溶離液として流速 $1 \mathrm{ml} / \mathrm{min}$ で測 定した。糖化率は, 生成糖の収率として（3）－（4）式を用い て算出した。

糖化率 (Sugar yield)（\%)

$=\frac{\text { 酵素糖化収率 }(\mathrm{mg} \text {-sugar } / \mathrm{g} \text {-residue }) \times \mathrm{SR} / 100}{\text { 単位乾燥重量あたりのヒノキの構成単糖量 }(\text { mg-sugar } / \text { g-material })} \times 100$

ここで,

酵素糖化収率(Enzymatic saccharification rate) (mg-sugar/g-residue)

酵素糖化で得られた糖量 $(\mathrm{mg})$

$=\frac{\text { 酵素糖化で用いた } \mathrm{AP} \text { 処理残椬乾燥重量 }(\mathrm{g})}{\text { ( }}$

酵素糖化収率は, 酵素糖化で用いた残椬 ( $\mathrm{AP}$ 処理残椬) $1 \mathrm{~g}$ から生成する糖量 $(\mathrm{mg})$ として算出した。

\subsection{X 線結晶回折解析 (X-ray diffraction : XRD)}

約 $100 \mathrm{mg}$ の試料を, 高圧ポンプを用いて錠剂状に成形し た後, Rigaku RINT-TTR3 X-ray diffractometer (Rigaku Co., Tokyo, Japan）を用いて X 線結晶回折分析を行った。 X 線 源として, CuKaを用いて, $50 \mathrm{kV}, 300 \mathrm{~mA} て ゙$ 照射し, スキャ ンレンジ $2-60^{\circ}$ ，スキャンスピード $2^{\circ} / \mathrm{min}$ で測定した。得ら れた回折強度から, Segal ら 22) の方法に従い, 式(5)を用い て結晶化度 (Crystallinity index : CrI) を求めた。

結晶化度 $(\mathrm{CrI} \%)=\left[\left(\mathrm{I}_{002}-\mathrm{I}_{\mathrm{am}}\right) / \mathrm{I}_{002}\right] \times 100$

$\mathrm{I}_{002}: 2 \theta=22.5^{\circ} ; \mathrm{I}_{\mathrm{am}}: 2 \theta=18.7^{\circ}$

\section{5 電界放出型電子顕微鏡 (Field emission scanning electron microscopy：FE-SEM）観察}

試料に四酸化オスミウム処理をした後, 電界放出型電子 顕微鏡 (Field-emission scanning electron microscopy; S-4800, Hitachi High-Technologies Co.) を用いて, 印加電圧 $1.4 \mathrm{kV}$ で試料表面の形態観察を行った。 


\section{3. 結果および考察}

3.1 種々条件の AP 処理ヒノキの酵素糖化試験および 主要組成

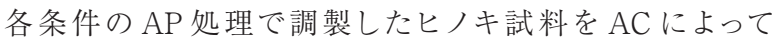

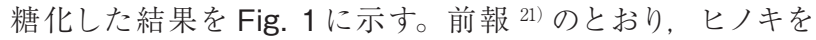
$6 \mathrm{M}$ 過酸化水素, $2 \mathrm{M}$ 水酸化ナトリウムとなる混合液中で $70^{\circ} \mathrm{C} ， 20$ 時間以上反応させた条件で高い糖化率を得た。過 酸化水素または水酸化ナトリウムのどちらか一方では, 温 度条件を変えても糖化率はほとんど増加しなかった。また, $90^{\circ} \mathrm{C}$ の応では, 糖化率が減少した。本実験で用いた過酸 化水素の MSDSによると, 熱分解速度は, $10^{\circ} \mathrm{C}$ の温度上昇で, 約 2.2 倍高まるため, $90^{\circ} \mathrm{C}$ の反応では過酸化水素の分解が 速やかに起こり，ヒノキ試料の酸化分解が十分に起こらな かったと考えられる。処理前の重量に対して, AP 処理後に 得られた固形分の重量を百分率で示したSR（\%）に着目す ると， SRが低い，すなわち AP 処理で重量損失が大きい試 料ほど糖化率が高い傾向にあったが，例外もあり，重量損 失に関わる溶出成分が重要であると示唆される。

各条件で得た AP 処理試料の重量損失に対して, 試料に 含まれる構成単糖および酸不溶性リグニン量をプロットした 結果をFig. 2 に示す。酸不溶性リグニン量およびへミセルロー ス由来のキシロース拈よびマンノースは，AP 処理における重 量損失の増加とともに緩やかに減少し, グルコースのみ増加

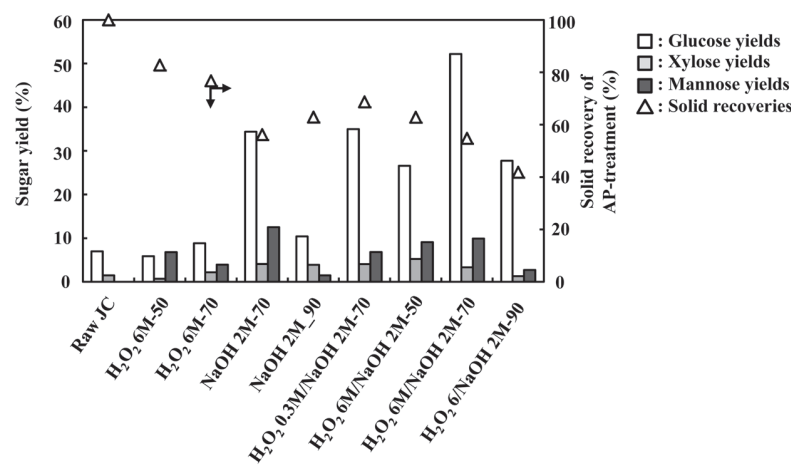

Fig. 1 Enzymatic hydrolyses of AP-treated Japanese cypress in various condition

Open bars: glucose yield; gray bars: xylose yield; closed bars: mannose yield; open triangles: solid recovery

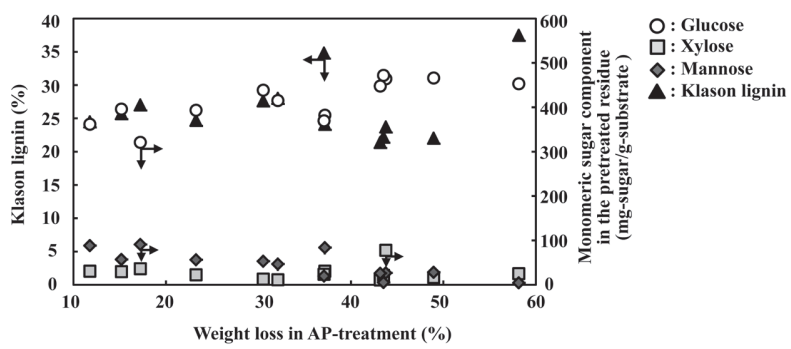

Fig. 2 Relationship between weight loss in AP-treatment and main components of residue

Open circles: glucose content; gray circles: xylose content; closed circles: mannose content; closed triangles: Klason lignin content
傾向にあった。これは重量損失が, 主にリグニンとへミセル ロースの溶出によるものであり, AP 処理残椬中に含まれるセ ルロースの割合が増加したことを示している。酸不溶性リグ ニン量の割合が処理前の $31.9 \%$ を有意に超える試料 $(\mathrm{NaOH}$ 2M-90, $\left.\mathrm{H}_{2} \mathrm{O}_{2} 6 \mathrm{M} / \mathrm{NaOH} 2 \mathrm{M}-90\right)$ があった。本試料は, へミ セルロースの構成単糖であるキシロースおよびマンノースの值 が他の試料に比べ相対的に低い(Table 1)。本試料の処理 条件では，へミセルロースの溶出が優先的に起こる一方で, 大部分のリグニンが残存し, 残椬中に含まれる見かけのリグ ニン割合が増加したと考えられる。先述のとおり, 過酸化水 素の熱分解温度は, $10^{\circ} \mathrm{C}$ の温度上昇で, 約 2.2 倍高まるた め, $90^{\circ} \mathrm{C}$ の反応では過酸化水素の分解が速やかに抗こと 考えられる。そのため, $\mathrm{H}_{2} \mathrm{O}_{2} 6 \mathrm{M} / \mathrm{NaOH} 2 \mathrm{M}-90$ の反応後半 は， NaOH 2M-90 と類似した状態になると予想される。結果 的に両処理残椬には, ヘミセルロース由来の構成単糖の割 合が低く、リグニンの割合が高いという類似した化学的組成 になっている。

最も糖化率の高い試料（ $\mathrm{H}_{2} \mathrm{O}_{2} 6 \mathrm{M} / \mathrm{NaOH} 2 \mathrm{M}-70 ）$ の全構 成単糖の約 $93 \%$ がグルコースであり，へミセルロース由来の キシロースおよびマンノースはわずか $3 \%$ および $4 \%$ \%あった。 $\mathrm{AP}$ 処理によって溶出される成分割合と糖化率の関係を明ら かにするため, 最も糖化率の高かった試薬および温度条件 を用いて, AP 処理時間に対する主要成分の残存率およびグ ルコース収率の経時変化を Fig. 3 に示す。なお, 主要成分 の残存率は, $\mathrm{AP}$ 処理前に含まれる成分の絶対量を 100 とし た時の值であり，SRを考慮し算出された。反応 3 時間で最 も残存率の低い成分はマンノースであり，次いでキシロース となり,リグニンおよびグルコースはほぼ同じ值であった。こ れらの成分の減少と伴に, 酵素糖化におけるグルコース収率 は約 4 倍増加した。さらに $\mathrm{AP}$ 処理反応時間を 6 時間にす ると, マンノースだけでなくキシロースの大部分も溶出し，わ
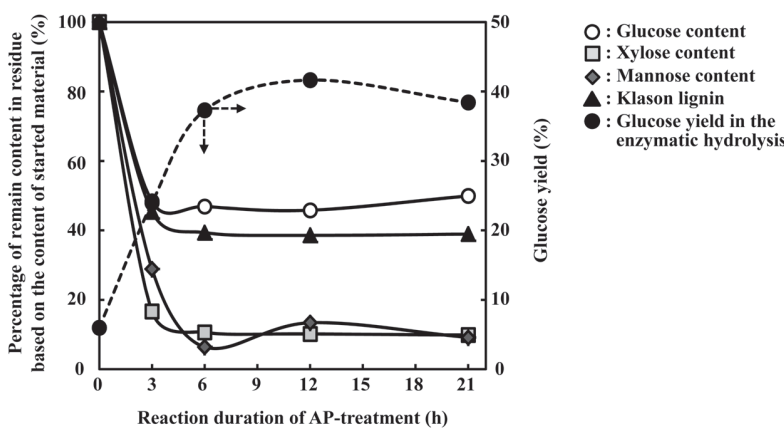

Fig. 3 Time course of remain-percentage of remain components and glucose yield of enzymetic hydrolysis in AP-treatment

Open circles: glucose; gray circles: xylose; closed circles: mannose; closed triangles: Klason lignin; closed circles: glucose yield in enzymatic hydrolysis Solid lines show the percentages of remain content in residues based on the content of started material: dashed-line show the glucose yield in the enzymatic hydrolysis. The percentage of remain component was calculated inconsideration of solid recovery. 
ずかにリグニンも減少したが，七ルロース由来のグルコース 成分はほとんど変わらなかった。酵素糖化のグルコース収率 はさらに大きく増加し, 最高值付近まで達した。しかし, 反 応時間が 12 時間以上になると, 各成分の減少も確認されず, 酵素糖化におけるグルコース収率もほぼ一定となった。AP 処理では，まず初めにヒノキに含まれるへミセルロースの大 部分が短時間で溶出し，その後リグニンの隇少が起こるこ とで，酵素糖化性が高まったと示唆される。AP 処理によっ て分解㧍よび溶出されやすいヒノキの主要成分を順に並べる と, ヘミセルロース,リグニン，セルロースとなった。

Huijgen ら ${ }^{23)}$ や Hideno ら ${ }^{24)}$ は，キシランの減少およびリ グニンの変性が確認された試料で, 酵素糖化性が増加した と報告しており, AP 処理ヒノキにおいても同様の傾向が確 認された。ヒノキのような針葉樹のリグニンは，コニフェリル アルコールを基本構造単位とし，リグニン分子鎖を形成して おり,リグニン分子鎖の化学結合の約 50\%は， $\beta$-O-4 結合 である。さらにリグニン分子鎖は互いに $\alpha$-アリルエーテル結 合を介し，３次元網目構造を形成している。AP処理では， 過酸化水素イオン (HOO) が強力な求核試薬として働き, $\cdot \mathrm{OH}$ や $\mathrm{O}_{2}$ ・等のラジカルを発生させる ${ }^{15)}{ }^{18)}$ 。これらのイオ ンやラジカルが，上記リグニンの $\beta$ - O-4 結合や $\alpha$-アリルエー テル結合を切断し，低分子化するとともに，一部は低分子リ グニンの縮重を引き起こすと考えられている 25) 26)。リグニン はへミセルロースと共有結合を有しており 27)，AP処理によっ てリグニンの低分子化や，リグニン周辺に存在するへミセル ロースの溶出が引き起こされることで, 残椬中のセルロース の割合が高まると同時に，セルロースに対する酵素のアタッ クが容易になり，糖化率が高まったと考えられる。

\subsection{X 線結晶回折解析}

$\mathrm{X}$ 線結晶回折解析では, 固体試料表面の数 $\mathrm{nm}$ オーダー の状態を解析しており，XRD スペクトラムから算出される見 かけの結晶化度を指標にすることによって，結晶性セルロー スの露出状態を大まかに推測できる。無処理ヒノキおよび $\mathrm{AP}$ 処理ヒノキの X 線回折強度スペクトラムを Fig. 4 に示す。 各試料のスペクトルに大きな違いは確認できず，いずれの処 理においても非晶化が起こらなかったことを示している。本 スペクトラムから算出した無処理ヒノキおよび $\mathrm{AP}$ 処理ヒノキ の結晶化度を Table 2 に示す。全体的な傾向として, 結晶化 度は $\mathrm{H}_{2} \mathrm{O}_{2}$ 濃度に影響を受けず，主に $\mathrm{NaOH}$ 濃度に影響を受 けており, $\mathrm{NaOH}$ 濃度が高い処理において, 結晶化度も高く なる傾向があった。糖化率の最も高い(f) $\mathrm{H}_{2} \mathrm{O}_{2} 6 \mathrm{M} / \mathrm{NaOH} 2$ M-70の結晶化度は，アルカリ処理のみの (c) NaOH 2 M-70 よりわずかに低かったものの，無処理に比べ高かった。一般 的にボールミル処理物については，七ルロースの結晶化度低 下と糖化性の向上に正の相関関係がある。しかし, リグノセ ルロースの酵素糖化に関わる要素は複雑であり, 結晶化度 の影響だけで考察するのは適切でないという報告もある ${ }^{28)}$ Endoは，木材のナノ構造の特性を活用するメカノケミカル 処理により，七ルロースナノファイバーを形成し，結晶性を保

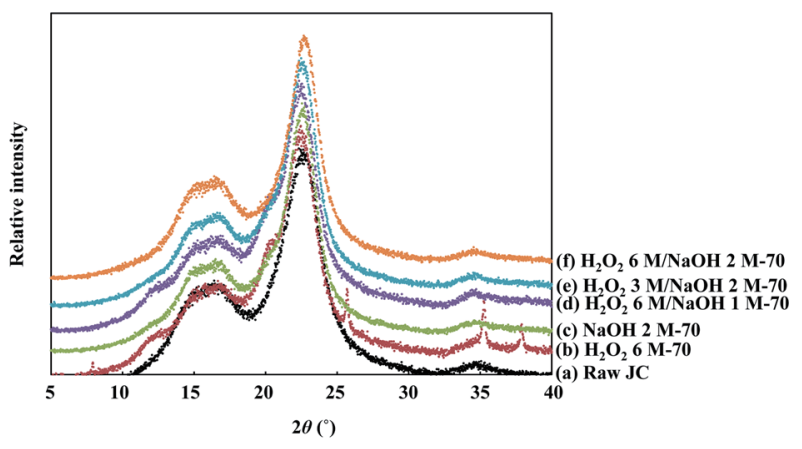

Fig. 4 Relative intensity in the X-ray diffraction spectrum of treated samples

(a) Raw JC, (b) $\mathrm{H}_{2} \mathrm{O}_{2} 6 \mathrm{M}-70$, (c) $\mathrm{NaOH} 2 \mathrm{M}-70$, (d) $\mathrm{H}_{2} \mathrm{O}_{2} 6 \mathrm{M} / \mathrm{NaOH} 1 \mathrm{M}-70$, (e) $\mathrm{H}_{2} \mathrm{O}_{2} 3 \mathrm{M} / \mathrm{NaOH} 2$ $\mathrm{M}-70$, (f) $\mathrm{H}_{2} \mathrm{O}_{2} 6 \mathrm{M} / \mathrm{NaOH} 2 \mathrm{M}-70$

Table 2 Crystallinity index (Crl) of AP-treated samples

\begin{tabular}{l|c}
\hline Sample name & CrI (\%) \\
\hline (a) $\mathrm{Raw}$ JC & 60.2 \\
\hline (b) $\mathrm{H}_{2} \mathrm{O}_{2} 6 \mathrm{M}-70$ & 60.5 \\
\hline (c) $\mathrm{NaOH}_{2} \mathrm{M}-70$ & 70.8 \\
\hline (d) $\mathrm{H}_{2} \mathrm{O}_{2} 6 \mathrm{M} / \mathrm{NaOH} 1 \mathrm{M}-70$ & 63.7 \\
\hline (e) $\mathrm{H}_{2} \mathrm{O}_{2} 3 \mathrm{M} / \mathrm{NaOH} 2 \mathrm{M}-70$ & 68.4 \\
\hline (f) $\mathrm{H}_{2} \mathrm{O}_{2} 6 \mathrm{M} / \mathrm{NaOH} 2 \mathrm{M}-70$ & 68.6 \\
\hline
\end{tabular}

持した状態で，糖化率を増加するという報告をしている ${ }^{29)}$ さらに Hidenoらは，稲わらの水熱処理物 ${ }^{17)}$ や，ヒノキのオ ルガノソルブ処理物の結晶化度が増加することを報告してい る ${ }^{24)} \mathrm{AP}$ 処理物においても，無処理ヒノキよりもわずかに 高い結晶化度の值を示した。水熱処理やオルガノソルブ処 理と同様，AP 処理によって，リグノセルロース表面のへミ セルロースやリグニンといった非結晶物が除去されることで, 高結晶性セルロースが露出したと考えられる。一方, $\mathrm{NaOH}$ 2 M-70 試料の SR は 56\%と, 溶出量が大きく, セルロースの 構成単糖であるグルコースの割合も比較的高い (Table 1) こ とから, 高結晶セルロースが露出している頻度が高いと考え られる。しかしながら，糖化率は $\mathrm{H}_{2} \mathrm{O}_{2} 6 \mathrm{M} / \mathrm{NaOH} 2 \mathrm{M}-70$ に 比べ低かった。Table 1 の結果から， NaOH 2 M-70 試料のキ シロースの割合は，その他試料の值よりも高く，酸不溶性リ グニン量については, $\mathrm{H}_{2} \mathrm{O}_{2} 6 \mathrm{M} / \mathrm{NaOH} 2 \mathrm{M}-70$ に比べてわず かに高い值であった。キシロースを構成糖とするキシランは, リグニンとは共有結合，セルロースとは非共有結合で繋がって おり，植物細胞壁の頑健性を保つ機能を果たすとともに，セ ルラーゼによる酵素糖化を阻害すると考えられている ${ }^{27) 。 ア ~}$ ルカリ処理のみの $\mathrm{NaOH} 2 \mathrm{M}-70$ 試料では, 結晶性セルロー スが露出しているものの, キシロースを構成単糖とするキシ ランが, リグニンと強固に結びつきながらセルロース周辺に 存在しているため, $\mathrm{H}_{2} \mathrm{O}_{2} 6 \mathrm{M} / \mathrm{NaOH} 2 \mathrm{M}-70$ に比べて糖化率 が低くなったと考えられる。

\section{3 ヒノキ前処理物表面の形態観察}

無処理ヒノキおよび AP 処理ヒノキの FE-SEM 写真を 
Fig. 5 に示す。無処理ヒノキの表面は滑らかで, 小孔や微 小繊維は見当たらなかった（Fig. 5 a)。一方で，AP 処理物 の表面には, ナノスケールの毛羽立ち (Fig. 5 b, 黒矢印) や, ナノファイバー（Fig. 5 c, 白矢印）が観察された。ヒノキの オルガノ処理物表面においても，七ルロースナノファイバーの 露出が観察されており (Fig. 5 d), 糖化率増加の要因と考え られている ${ }^{24)}$ 。Endoは, 湿式メカノケミカル処理により, リ グニンが残存し，高結晶性を保持した状態であってもナノ緎 維まで解すことで高糖化率が可能であると報告している ${ }^{29)}$ $\mathrm{AP}$ 処理物でも同様のファイバーが確認されており, 結晶化 度および糖化率増加の要因であることが示唆される。しか し, AP 処理物では, このようなナノファイバーよりナノスケー ルの毛羽立ちがより多く観察された。この形態は AP 処理物 特有であり, 糖化率増加の要因として考えられる初めてのナ ノ形態である。

オルガノソルブ処理物表面では，七ルロースナノファイバー の他に,リグニン球が確認されている ${ }^{24)}$ (Fig. 5 e, 白矢印)。 リグニン球は，木材中のリグニンが溶解，固化したリグニン 変性物と考えられている18)。これらリグニン球の存在もあり, オルガノソルブ処理物に残存する酸不溶性リグニンは約 $70 \%$ と多く, 処理試料の外見は焦げ茶色であった。一方, 本研 究の AP 処理物表面には, そのようなリグニン球は確認され ず, SR を考慮した残存リグニンも約 40\%程度であり (Fig. 3), 外見もほぼ白色であった。AP処理では, 過酸化水素イオン ( $\left.\mathrm{HOO}^{-}\right)$や· $\mathrm{OH}$ や $\mathrm{O}_{2} \cdot$ 等のラジカルが, リグニンの芳香環
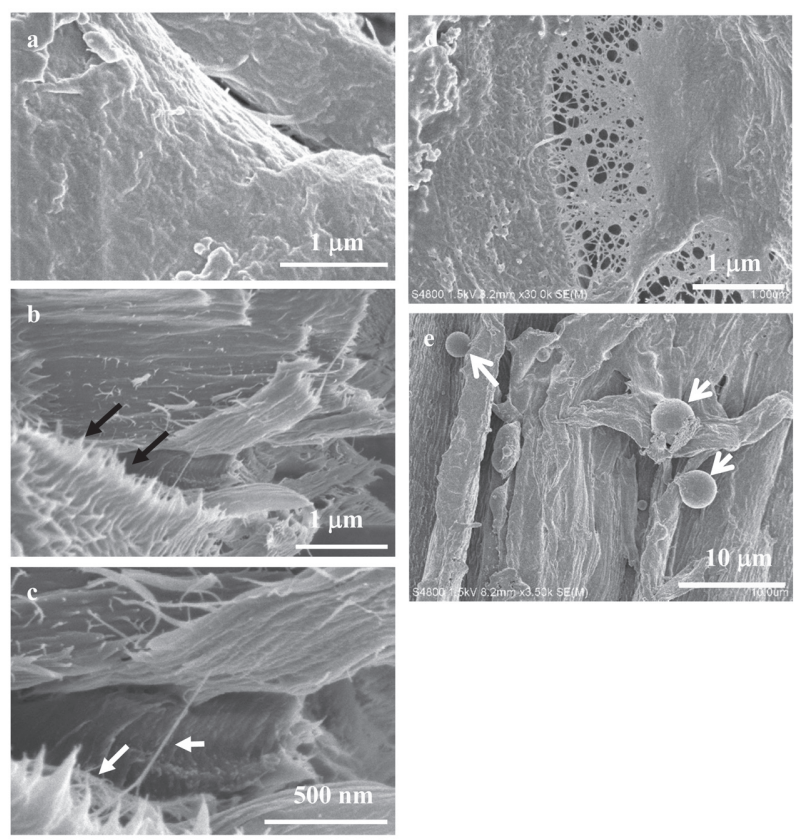

Fig. 5 Field emission scanning electron microscope photographs of AP-treated samples a: Raw JC ( $\times 30,000)$, b: $\mathrm{H}_{2} \mathrm{O}_{2} 6 \mathrm{M} / \mathrm{NaOH} 2 \mathrm{M}-70$ ( $\times$ 30,000), c: $\mathrm{H}_{2} \mathrm{O}_{2} 6 \mathrm{M} / \mathrm{NaOH} 2 \mathrm{M}-70(\times 45,000)$, d: EtOH50/W50/HClO.4 ( $\times 30,000)$, e: EtOH50/W50/ $\mathrm{HClO} .4(\times 3,000)$

The photos of $d$ and $e$ are the modified citations of Hideno et al. ${ }^{24)}$.
やアリルエーテル結合を分解していると考えられており ${ }^{25)}$, 本 処理で低分子化されたリグニンは再び固化することなく、さ らに低分子溶解物または $\mathrm{CO}_{2}$ まで酸化分解されたと示唆さ れる。

\subsection{AP 処理物に対する糖化酵素の至適化}

低コストな木質系バイオエタノール生産を目指す上で，糖 化工程の改善も前処理と同様に重要である。本研究では, 糖化酵素として AC を中心に使ってきた。本酵素は我が国 で育種されたAcremonium cellulolyticus ${ }^{31)}$ の変異株由来で あり, 従来の Trichoderma reesei 由来の市販酵素より, $\beta$ -glucosidase 比活性や耐熱性が高いことで知られている。そ のため, $50^{\circ} \mathrm{C}$ 付近で長時間の糖化を行っても, セロビオース の蓄積が少なく効率良くセルロースを糖化できる。しかし， 最近, 世界的な酵素メーカーがT. reeseiの遺伝子工学的育 種や培養法の開発を行い, 従来よりも $\beta$-glucosidase 比活性 が高い酵素の生産や，大幅な低コスト化を実現している ${ }^{32}$ 。 そこで, AP 処理物の糖化に適した酵素カクテルを調製する ため, これまで用いてきた ACに加え，2009 年に Genencor 社が発売した ACC1500 をべース酵素として, それらにアクセ サリー酵素 3 種をそれぞれ組み合わせた糖化試験を行った (Fig. 6)。ACに対して相乗効果を示すアクセサリー酵素は, OPXL およびACC1500 であり，ACC1500の添加効果が最も 効果が高かった。しかし，ACC1500を単独で用いた結果， さらに糖化率は増加した。一方, ACC1500 に対するアクセサ リー酵素の添加効果は確認できなかった。以上の結果から, $\mathrm{AP}$ 処理物の至適糖化酵素は, ACC1500 単独であった。

さらに $\mathrm{ACC} 1500$ の酵素添加量を減らしても, ACより 高い糖化率を示した (Fig. 7)。ACでは 80 mg-protein/ g-substrateで達成した糖化率を，ACC1500では 1/4の 20

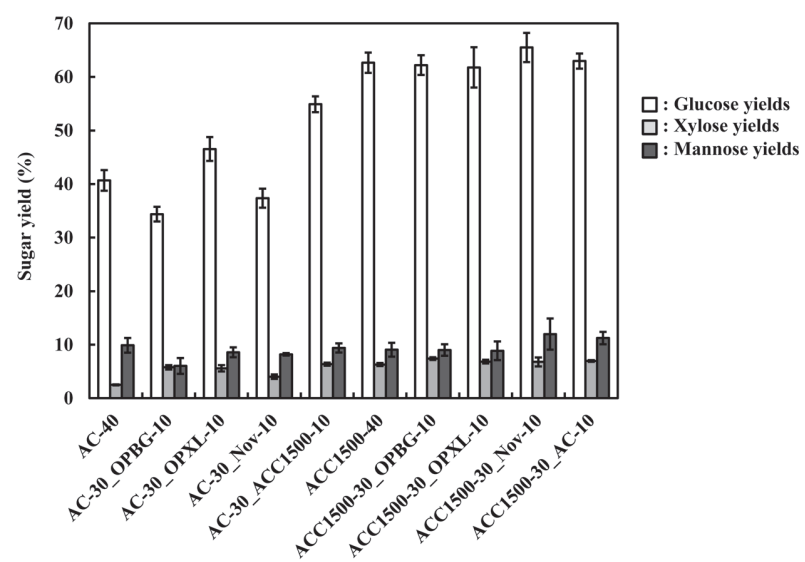

Fig. 6 Enzymatic hydrolysis of AP-treated sample using various commercial enzymes

Open bars: glucose yield; gray bars: xylose yield; closed bars: mannose yield

AC: Acremonium cellulase; ACC1500: Accellease 1500; OPBG: Optimash BG; OPXL: Optimash XL; Nov: Novozyme 188

The numbers mean the loading protein amounts (mgprotein) per g-substrate. 


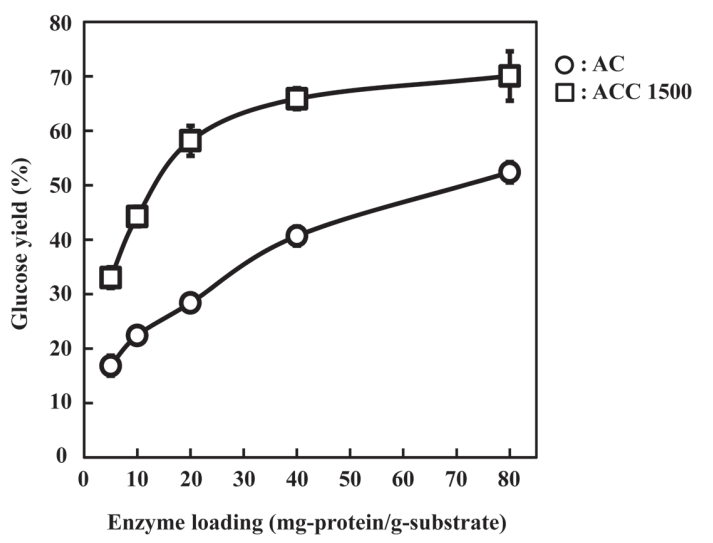

Fig. 7 Comparison of Acremonium cellulase and Accellerase 1500 with different loading protein Open circles: AC; open squares: ACC1500

The substrate was used $\mathrm{H}_{2} \mathrm{O}_{2} 6 \mathrm{M} / \mathrm{NaOH} 2 \mathrm{M}-70$

mg-protein/g-substrate で超える結果となった。酵素コストは バイオエタノール生産プロセス全体に占める割合が大きく ${ }^{111}$, 酵素使用量の削減はコス卜低下に繋がるため, AP 処理物に 対して ACC1500を使用することで，コスト低滅に寄与できる と考えられる。

$\mathrm{AP}$ 処理物では, 大部分のへミセルロースおよび半量以上 のリグニンが分解され，その表面に高結晶性セルロースが, ナノスケールの繊維または毛羽立ちとなって現われている (Figs. 4, 5)。同様に, 結晶化度が高く, その表面上にセルロー スナノファイバーが露出しているオルガノソルブ処理物でも, 至適酵素として ACC1500 が選択されている24)。ACC1500は このような高結晶性セルロースが露出した基質の糖化に適し ている組成を有していると考えられる。AC および ACC1500 の酵素比活性を比較すると, FPU 比活性はほぼ同じであり, $\beta$-glucosidase 比活性については ACC1500 がわずかに AC より高く，微結晶セルロースを基質としたセルラーゼ比活性 の比較では, ACC1500が ACの約 3 倍高かった (Data not shown)。 $\beta$-glucosidase 比活性の高い Nov を ACに添加して も糖化率が増加しなかったことや， ACの添加量を増やして も，1/4 量の ACC1500の糖化率に及ばないことから，結晶 性セルロース分解に関して, ACC1500 特異的に含まれる酵素 や，酵素1分子の機能差が重要な役割を果たしていると示唆 される。濾紙分解活性であるFPUは，七ルラーゼ活性の指 標としてよく用いられてきたが，必ずしもバイオマスの糖化性 と一致するわけではない。今後, Cel7Aのような結晶性セル ロース分解酵素 1 分子の詳細な解析や, 生産菌株間に打け る酵素分子の性能比較が必要であろう。

本研究により，木材に対する AP 単独処理の有効性およ び AP 処理物の糖化に適した酵素が明らかになった。競争 力の無くなった旧型製紙工場を有効活用した木質系バイオエ タノール生産を想定する際, AP 処理法は簡易かつ有効な前 処理法の一つとして提案できる。

\section{4. 結 論}

ヒノキの高効率酵素糖化を目指し, AP 処理条件として $6 \mathrm{M} \mathrm{H}_{2} \mathrm{O}_{2}$ および $2 \mathrm{M} \mathrm{NaOH}$ の混液中にて $70^{\circ} \mathrm{C}, 12$ 時間以上 の反応が最適であることが明らかとなり，それぞれ AP 処理 物の化学組成および物性を解析し, 至適酵素を検討した結 果, 以下の知見が得られた。

(1) AP 処理後の重量損失が大きい試料が高糖化率を示す傾 向にあった。AP 処理によって分解および溶出されやすい ヒノキの主要成分を順に並べると，へミセルロース，リ グニン，セルロースとなった。特に酵素糖化率増加に影 響が大きかったのは，へミセルロースのキシランおよびリ グニンの分解および溶出であった。

(2) AP 処理物の結晶化度は無処理試料よりもわずかに高く, 表面はナノスケールの毛羽立ちおよびセルロースナノファ イバーが観察された結果から，高結晶セルロースが表面 に露出していることが明らかになった。ナノスケールの毛 羽立ちは, AP 処理特有の形態であり, 糖化率増加に寄 与するものと示唆された。

(3) AP 処理物の酵素糖化に際し, ACC1500 が至適酵素であ り, ACの $1 / 4$ 量で同等以上の糖化率が得られたことから, 酵素コスト低減化が可能となった。

\section{謝 辞}

本研究は, (1) 平成 $21 \sim 24$ 年度科学技術振興調整費「若 手研究者の自立的研究環境整備促進」プログラム, (2) 平 成 22 年度松籟科学技術振興財団研究助成金, (3) 平成 22 ～ 24 年度科学研究費補助金 (若手 B, 22780292) の支援で 行われた。酵素については, 明治製菓(株), ジェネンコア 協和(株)，ノボザイム・ジャパン(株)，並びに産業技術総合 研究所 井上宏之研究員, 愛媛大学 渡辺誠也准教授に御提 供頂いた。ここに記して謝意を表する。

\section{文 献: References}

1) Yoshimura, T.; Inoue, S.: J. Jpn. Inst. Energy, 90(3), 268(2011)

2) Philips, R. B.; Jameel, H.; Chang, H.: Research Progress in Pulping and Papermaking, p. 11 (2006)

3) Nonaka, H.: The Bullein of the Graduate School of Bioresources, Mie University, 35, 71 (2008)：野中寛, 三重大学大学院生 物資源学研究科紀要, 35, 71 (2008)

4) Nonaka, H.; Nakagawa, A.: J. Jpn. Inst. Energy, 89 (10), 962 (2010)

5) Ministry of Agriculture, Forestry and Fisheries homepage (for Japanese) : バイオマス・ニッポン総合戦 略, http://www.maff.go.jp/j/biomass/pdf/riyo_zyokyo. pdf (2013/3/4 参照)

6) Kobayashi, N.; Ushikoshi, J.; Inano, M.; Takaoka, K.; Itaya, Y.: J. Jpn. Inst. Energy, 89, 975 (2010)

7) Forestry Agency in Ministry of Agriculture, Forestry and Fisheries, Japan, Heisei 24 nendo shinrin ringyou hakusyo, pp. 85 : 林野庁, 平成 24 年度森林·林業白書, 
pp. 85

8) Uemura, T.; Mizuishi, H.; Kano, H.: Chitekisisansouzou, Apr., 54 (2010): 植村哲士, 水石仁, 科野宏典, 知的資産創造, 4月号, 54 (2010)

9) Okuda, N.; Ninomiya, K.; Takao, M.; Katakura, Y.; Shioya, S.: J. Biosci. Bioeng., 103, 350 (2007)

10) Ohtsuki, T.; Noda, S.; Ui, S.: Canadian J. Pure Appl. Sci., 5 , 1333 (2011)

11) Hamelinck, C. N.; Hooijdonk, G. V.; Faaij, A. P C.: Biomass Bioenerg., 28 (4) , 384 (2005)

12) Sun, Y.; Cheng, J.: Bioresour. Technol., 83, 1 (2002)

13) Tolan, J. S.: Clean Techn. Environ. Policy, 3, 339 (2002)

14) Teymouri, F.; Laureano-Perez, L.; Alizadeh, H.; Dale, B. E.: Bioresour. Technol., 96, 2014(2005)

15) Gould, J. M.: Biotechnol. Bioeng., 27, 893(1984)

16) Banerjee, G.; Car, S.; Liu, T.; Williams, D. L.; Meza, S. L.; Walton, J. D.; Hodge, D. B.: Biotechnol. Bioeng., 109, 922 (2011)

17) Monte, J. R.; Brienzo, M.; Milagres, A. M. F.: Appl. Energ., 88, 403 (2011)

18) Selig, M. J.; Viamajala, S.; Decker, S. R.; Tucker, M. P.; Himmel, M. E.; Vinzant, T. B.: Biotechnol. Prog., 23, 1333 (2007)

19) Yamamoto, T.; Saitou, Y.; Taki, H.; Terashima, K.; Kaneko, S.: Taiseikenshutsu gijyutsusenntahou, 40, 1 (2007) : 山本哲史, 斎藤祐二, 瀧寛則, 寺島和秀, 金子誠二, 大成建設技術 センター報, 40, 1 (2007)

20) Sluiter, A.; Hames, B.; Ruiz, R.; Scarlata, C.; Sluiter, J.; Templeton, D.; Crocker, D.: Laboratory analytical procedure (LAP), Technical report NREL/TP-510-42618 (2008)

21) Hideno, A.; Kawashima, A.; Honda, K.; Morita, M.: 6th Biomass kagaku kaigi happyou ronbunsyuu, (The Japan Institute of Energy), p. 96 (2010)：秀野晃大, 川嶋文人, 本田克久, 森田昌敏, 第 6 回バイオマス科学会議発表論 文集,（日本エネルギー学会）, p. 96 (2010)

22) Segal, L.; Creely, J. J.; Martin, A. E.; Conrad, C. M.: Text. Res. J., 29, 786 (1959)

23) Huijgen, W. J. J.; Smit, A. T.; Wild, P. J. D.; Uil, H. D.: Bioresour. Technol., 114, 389 (2012)

24) Hideno, A.; Kawashima, A.; Endo, T.; Honda, K.; Morita, M.: Bioresour. Technol., 132, 64 (2013)

25) Xiang, Q.; Lee, Y. Y.: Appl. Biochem. Biotechnol., 84-86, 153 (2004)

26) Li, M.; Foster, C.; Kelkar, S.; Pu, Y.; Holmes, D.; Ragauskas, A.; Saffron, C.; Hodge, D. B.: Biotechnol. Biofuel., 5, 38 (2012)

27) Zhang, Y. H. P.. J. Ind. Microbiol. Biotechnol., 35, 367 (2008)

28) Park, S.; Baker, J. O.; Himmel, M. E.; Parilla, P. A.; Johnson, D. K.: Biotechnol. Biofuels, 3, 10 (2010)

29) Endo, T:: Synthesiology, 2, 310 (2009)

30) Hideno A.; Inoue, H.; Tsukahara, K.; Fujimoto, S.; Minowa, T.; Inoue, S.; Endo, T.; Sawayama, S.: Bioresour. Technol., $100(10), 2706(2009)$

31) Yamanobe, T.; Mitsuishi, Y.; Takasaki, Y.: Agric. Biol. Chem., 51, 65 (1987)

32) Sustainable Business.com., http://www.sustainablebusiness. com/index.cfm/go/news.display/id/19769 (Accessed on 2013/3/4) 